\title{
Climate change and crop adaptation in Spain: consistency of regional climate models
}

\author{
A. Garrido ${ }^{1, *}$, D. Rey $^{2}$, M. Ruiz-Ramos ${ }^{3}$, M. I. Mínguez ${ }^{4}$ \\ ${ }^{1}$ ETSIA and ${ }^{2}$ CEIGRAM, Technical University of Madrid, 28040 Madrid, Spain \\ ${ }^{3}$ Instituto de Ciencias Ambientales, University of Castilla-La Mancha, 45071 Toledo, Spain \\ ${ }^{4}$ Agricultural Systems Group, Depto. Producción Vegetal: Fitotecnia, Technical University of Madrid, 28040 Madrid, Spain
}

\begin{abstract}
This work analyses projections of agricultural impacts obtained with an ensemble of 10 regional climate models (RCMs) from the European project PRUDENCE, applied to yields of winter and summer crops. Projections were evaluated for 12 sites of the Iberian Peninsula for the 2071-2100 period, taking 1961-1990 as the control period or baseline. Future prospects for agriculture require quantifying the variability and discrepancy between results obtained from the modelling chain RCMs-crop models, i.e. the climate-impact ensemble, as well as the possible benefits drawn from the adaptation strategies of agriculture to the new climate conditions. Consistency within the climate-impact ensemble members was assessed by ranking comparisons of both projected yield impacts and yield changes. Adaptation strategies were simulated for cropping options having low uncertainty projections of yield decrease, as was the case for fully irrigated maize. The consistency between the 10 RCMs per crop and site was classified as generally moderate. Consistency among RCMs was greater both in rainfed and irrigated farming of winter cereals in N-plateau, NE-Valley, NW-Inland, Centre and NE, and very low in maize in the NW-Coast for example. RCM inconsistencies are a source of uncertainty in predicting climate change (CC) impacts on agriculture. Ranking comparisons of yield changes among different sites and cropping options gave even lower ensemble consistency, which shows the difficulty in projecting yield changes resulting from CC.
\end{abstract}

KEY WORDS: Climate change Crop yield $\cdot$ Maize $\cdot$ Wheat - Iberian Peninsula $\cdot$ RCMs Uncertainty

\section{INTRODUCTION}

Agriculture will be one of the sectors most affected by climate change (CC) because of its dependence on climate and edaphic conditions (Ainsworth \& Long 2005, PRUDENCE 2005, Easterling et al. 2007, Tubiello \& Fischer 2007, European Commission 2008, Iglesias \& Medina 2009). In their review, Kang et al. (2009) showed that the likely impacts of CC on crop yields vary significantly across regions and between species.

Regional Climate Models (RCMs) have a resolution of $50 \times 50 \mathrm{~km}$ to $20 \times 20 \mathrm{~km}$, and have been calibrated and validated with historical data (PRUDENCE pro- ject, Prediction of Regional scenarios and Uncertainties for Defining EuropeaN Climate change risks and Effects, http://prudence.dmi.dk/). In the framework of PRUDENCE, Jacob et al. (2007) compared the Climate Research Unit (CRU) database (Hulme et al. 1995) with the RCM projections. The RCMs enabled the analysis of impacts in small geographic units, allowing a description of the effects linked to the specific features of each site considered. CC effects at a regional scale are still subject to significant errors (Schiermeier 2010); thus, RCM comparisons may indicate impact discrepancies as well as concurrences.

The Iberian Peninsula (IP) is characterized by its large variety of climate and orographic conditions in 
a not very large land extension. Therefore, effects of climate on crops are expected to vary across crops and locations (Ruiz-Ramos \& Mínguez 2010). Thus it is not possible to describe a uniform impact of CC on the agriculture of a whole country (Guereña et al. 2001, Moreno 2005, Iglesias \& Quiroga 2007, Mínguez et al. 2007). Despite the difficulty in assessing CC impact on European agriculture due to the effect of potential policies, market influence and continuous technological development, there is clear evidence of vulnerability in this sector (Lavalle et al. 2009). García \& Viladrich-Grau (2009) concluded that $\mathrm{CC}$ will raise the price of agricultural land all over Spain, increasing its economic productivity as a result of increased temperatures. Iglesias \& Quiroga (2007) showed that aggregated yields in Spain may vary from a $26 \%$ increase to a $19 \%$ decrease, depending on the $\mathrm{CC}$ scenario and time frame.

Climate projections from the various RCMs in combination with crop models, provide yield projections for a large number of sites and cropping options, and enable evaluation of associated uncertainties. There are large differences among RCM projections for the same sites (Christensen \& Christensen 2007). Our work analyses the consistency among the members of a climate-impact ensemble obtained using 10 RCMs. It also attempts to explain the consequences of RCM inconsistencies in the projection of CC impact on the yields of 2 reference crops used as indicators (wheat, representing winter rainfed and irrigated cropping options; and maize, representing summer irrigated cropping options). Our work complements the results obtained by Ruiz-Ramos \& Mínguez (2010) where cropping option and site were studied as uncertainty sources, identifying maximum and minimum uncertainty for both factors. The current work addresses another aspect of the uncertainty: how rankings of yield projections and their changes (impacts) driven by each RCM data (hereafter 'ranking of RCMs'), and therefore ensemble consistency, were affected by cropping option and site. Finally, the effect derived from the implementation of adaptation strategies to reduce negative effects of CC (OECC 2006) was studied for a summer cropping option.

\section{METHODOLOGY}

\subsection{Impact and adaptation projections}

The 10 RCMs of the PRUDENCE project that make up the climate ensemble are: HIRHAM (DMI), ARPEGE (CNRM), HadRM3H (HC), CHRM (ETH),
CLM (GKSS), REMO (MPI), RCAO (SMHI), PROMES (UCLM), RegCM (ICTP) and RACMO (KNMI). Eight RCMs were nested in the HadAM3H while 2 RCMs, ARPEGE and RCAO, used the boundary conditions of the AOGCMs ARPËGE/OPA and ECHAM/OPYC4, respectively (Christensen \& Christensen 2007).

The ensemble of impacts was built by simulating crop yields in various representative agricultural sites of the IP (Mínguez et al. 2007, Ruiz-Ramos \& Mínguez 2010) using 2 crop simulation models (CERES-Wheat and CERES-Maize models included in the DSSAT, Decision Support System for Agrotechnology Transfer; Tsuji et al. 1994, Jones et al. 2003), using daily climate data from each RCM from the climate ensemble. A complete description of the methodology used for these simulations can be found in Mínguez et al. $(2004,2007)$ and Olesen et al. (2007). Briefly, the variables used were rainfall, solar radiation, maximum and minimum temperatures, relative humidity and wind speed. The yield was considered an indicator integrating the effects of $\mathrm{CC}$ on crops. The ensemble of impacts consists of 10 members per simulated cropping option. One cropping option was irrigated maize representing summer cropping options, while the other was autumn wheat sowings for either winter (with vernalisation requirements) or spring wheat, both rainfed and irrigated, representing winter cropping options. No other limiting factor aside from water in rainfed simulations was considered. Maize and wheat have different photosynthetic systems and growing periods that span different seasons, and thus respond differently to temperature changes and to a rise in atmospheric $\mathrm{CO}_{2}$ concentration (Ainsworth \& Long 2005). These were used as reference crops, which were employed to assess the performance of a given cropping option in different sites, rather than assessing the CC impact on a particular crop (Mínguez et al. 2007).

The study was focused on the projections obtained for 12 sites representative of important agricultural areas in the IP (only 6 for winter wheat analysis) (Fig. 1), as in Ruiz-Ramos \& Mínguez (2010). When ordered from north to south these were: NW-Coast (La Coruña), NW-Inland (Lugo), NE (Navarra), NEValley (Zaragoza), N-Plateau (Valladolid), Center (Madrid), S-Plateau 1 (Toledo), S-Plateau 2 (Albacete), SW-Inland (Badajoz), SE-Coast (Murcia) and SValley 1 \& 2 (Córdoba, 2 sites differing only in soil type). For given sites and cropping options, simulations provided potential yields as well as yields under rainfed conditions both for the periods 1961-1990 (control) and 2071-2100 under the SRES A2 IPCC scenario that considers 635-856 ppm $\mathrm{CO}_{2}$ as future 


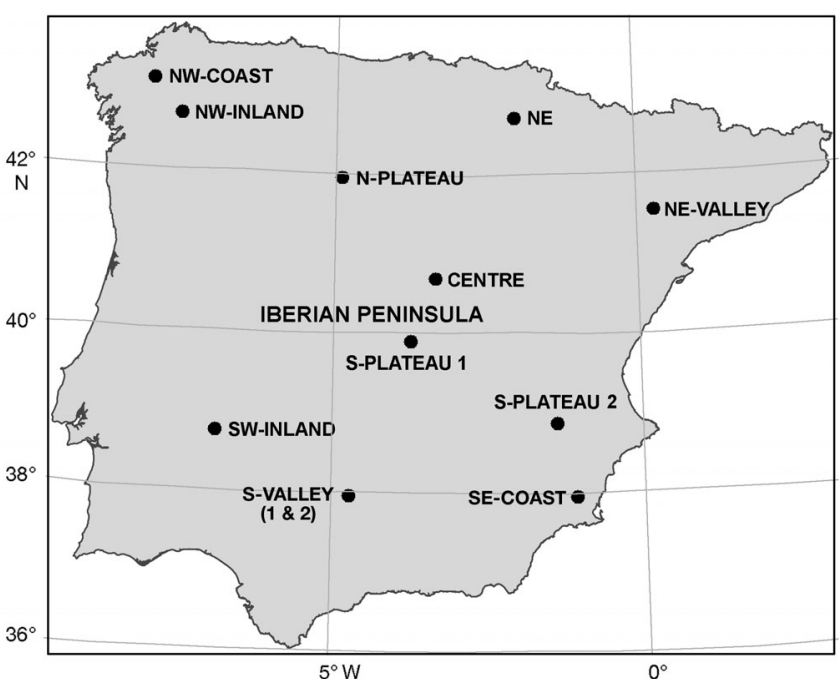

Fig. 1. Iberian Peninsula: the 12 sites under study. Altitude above sea level (a.s.l.) for each site-NW-Inland, NW-Coast and SE-Coast regions: $<50 \mathrm{~m}$; NE-Valley, SW-Inland and S-Valley (1 and 2): 100-250 m; NW-Inland and NE: 450 and $500 \mathrm{~m}$ (close to mountain areas); N-Plateau, Centre and S-Plateau (1 and 2): 550-700 m

greenhouse gas emissions (Nakicenovic \& Swart 2000). Table 1 shows the weather classification, the main climatic features and the cropping patterns of winter and summer crops in these locations. Crop duration of the cultivated varieties used in the simulations generally increases from south (shorter duration) to north (longer): 150 to $160 \mathrm{~d}$ for maize, 220 to $260 \mathrm{~d}$ for spring wheat, and 250 to $290 \mathrm{~d}$ for winter wheat.

The crop models used in this study have been previously calibrated and validated for various Iberian locations and crops (for southern locations: Mariscal
1993, Rebollo 1993; for SW, NE, N, S and Centre Plateau: Iglesias \& Mínguez 1995; for NW: LópezCedrón et al. 2005; for wheat and maize applicable to all IP: Quemada et al. 1997). Methodology related to the modeling chains (RCM-crop model) and most yield projections have been described in Mínguez et al. $(2004,2007)$, Olesen et al. (2007) and Ruiz-Ramos \& Mínguez (2010).

\subsection{Differences between yield projections and impacts among ensemble members: analysis of the ensemble's internal consistency}

Projections of yield obtained by each ensemble member were compared using the rank correlation coefficient (Kendall's Tau, $\tau$ statistic) to measure the degree of consistency among ensemble members across time period, sites, and cropping options. Ensemble consistency was tested by comparing the annual ranking of yields projected by the $10 \mathrm{RCMs}$ for a particular site, time reference and crop with the ranking of the same $10 \mathrm{RCMs}$ and time reference but for a different crop or site. Because rank comparisons will be made using only 10 pairs, the statistical significance of the $\tau$ s was set at $90 \%$. Intuitively, if yields obtained with different RCMs for a particular situation (crop and site) rank similarly as others for a different situation (crop or site), then one can conclude that some RCMs will systematically overshoot yield projections while others will underestimate them.

Rankings were drafted in descending order of the ensemble members from greater to lesser yield projection. Ranking of a cropping option and specific

Table 1. Climate classification, main climatic features and cropping pattern of winter and summer crops in the Iberian Peninsula.

T: temperature. Precipitation distribution (wet seasons): A: autumn; W: winter; S: spring

\begin{tabular}{|c|c|c|c|c|c|c|c|}
\hline \multirow[b]{2}{*}{ Location } & \multirow[b]{2}{*}{$\begin{array}{l}\text { Annual } \\
\text { mean T } \\
\left({ }^{\circ} \mathrm{C}\right)\end{array}$} & \multirow[b]{2}{*}{$\begin{array}{c}\text { Annual } \\
\text { mean T max } \\
\left({ }^{\circ} \mathrm{C}\right)\end{array}$} & \multirow[b]{2}{*}{$\begin{array}{l}\text { Annual } \\
\text { mean T min } \\
\quad\left({ }^{\circ} \mathrm{C}\right)\end{array}$} & \multirow[b]{2}{*}{$\begin{array}{c}\text { Annual } \\
\text { precipitation } \\
(\mathrm{mm})\end{array}$} & \multicolumn{3}{|c|}{ Cereal cropping systems sowing dates } \\
\hline & & & & & $\begin{array}{c}\text { Climate } \\
\text { classification } \\
\text { by Köppen }\end{array}$ & $\begin{array}{c}\text { Summer } \\
\text { crop } \\
\text { (maize) }\end{array}$ & $\begin{array}{l}\text { Winter } \\
\text { crop } \\
\text { (wheat) }\end{array}$ \\
\hline NW-Coast & 14.4 & 17.4 & 11.4 & $1008(\mathrm{~A}, \mathrm{~W})$ & Marine west coast, mild & 16 May & 10 Oct-10 Nov \\
\hline NW-Inland & 11.5 & 16.8 & 6.3 & $1084(\mathrm{~A}, \mathrm{~W})$ & & & \\
\hline NE & 12.5 & 17.8 & 7.1 & $721(\mathrm{~S}, \mathrm{~A}, \mathrm{~W})$ & & & \\
\hline N-Plateau & 11.1 & 17.2 & 4.9 & $455(\mathrm{~S}, \mathrm{~A})$ & Mediterranean, humid subtropical & & \\
\hline NE-Valley & 15.0 & 20.4 & 9.5 & $318(\mathrm{~S}, \mathrm{~A})$ & Steppe (cool), semi-arid & & \\
\hline Center & 14.1 & 20.6 & 7.6 & $386(\mathrm{~S}, \mathrm{~A})$ & Mediterranean, humid subtropical & 16 Apr & \\
\hline S-Plateau 1 & 15.4 & 21.4 & 9.3 & $357(\mathrm{~S}, \mathrm{~A})$ & & & \\
\hline S-Plateau 2 & 13.6 & 20.1 & 7.1 & $367(\mathrm{~S}, \mathrm{~A})$ & Steppe (cool), semi-arid & & \\
\hline SW-Inland & 16.6 & 23.3 & 9.9 & $463(\mathrm{~A}, \mathrm{~W})$ & & 30 Mar & $10 \mathrm{Nov}$ \\
\hline SE-Coast & 17.8 & 24.4 & 11.2 & $301(\mathrm{~S}, \mathrm{~A})$ & Steppe (hot), semi-arid & & \\
\hline S-Valley & 17.6 & 24.6 & 10.7 & $536(\mathrm{~S}, \mathrm{~A}, \mathrm{~W})$ & Mediterranean, humid subtropical & & \\
\hline
\end{tabular}


site was done for every year. Kendall's Tau was formulated as:

$$
\tau=\frac{n_{c}-n_{d}}{\frac{1}{2} n(n-1)}
$$

where $n_{C}$ is the number of concordant pairs; $n_{d}$ is the number of discordant pairs; and $n$ is the total number of pairs (in this case, number of members of the ensemble, 10). In comparing 2 ranks with each other, a concordant pair of 2 cropping options $\left(i, i^{\prime}\right)$ is one meeting the following formula:

$\operatorname{sgn}\left(Y_{i, j, t, m_{1}, h_{2}}-Y_{i, j, t, m, h_{1}}\right)=\operatorname{sgn}\left(Y_{i^{\prime}, j, t, m, h_{2}}-Y_{i^{\prime}, j, t, m_{1}, h_{1}}\right)$

where $Y$ denotes projected yield; $i$ is the cropping option $(1 \ldots 5) ; j$ is the site $(1 \ldots 12) ; m$ is the period $(0$, 1 ; control or A2); $t$ is the year $(1 \ldots 29)$; and $h$ is the RCM (1...10). Discordant pairs are those meeting these criteria:

$\operatorname{sgn}\left(Y_{i, j, t, m, h_{2}}-Y_{i, j, t, m, h_{1}}\right)=-\operatorname{sgn}\left(Y_{i^{\prime} j, t, m, h_{2}}-Y_{i^{\prime}, j, t, m, h_{1}}\right)$

where $\operatorname{sgn}_{\mathrm{x}}=-1$ if $\mathrm{x}<0$; 0 if $\mathrm{x}=0$ ( $\mathrm{x}$ being any bracketed term in Eq. 2), and 1 if $\mathrm{x}>0$, keeping $j$, $t$, and $m$ constant for the cropping options comparison $\left(i, i^{\prime}\right)$. The ensemble's internal consistency was checked with the yields' ranking of the $10 \mathrm{RCMs}$ for a pair of comparable cropping options, year and site.

Kendall's $\tau$ measures the correspondence of 2 projection rankings arranged in accordance with the estimated yield value. In this way, the statistic will be 1 when there is total correspondence; -1 when both rankings of RCMs are in the opposite order; between -1 and 1 , the higher the value of the statistic, the greater the degree of correspondence between the rankings. With a Kendall's $\tau$ close to 1 , there are some ensemble members that systematically provide yield values higher than the rest, whereas some members provide lower results than the rest; thus, they get arranged in a similar way in all cases. The consistency of the ensemble was compared both for the present and for the future climate.

From these rankings of RCMs (i.e. yield projections driven by each RCM data), it was possible to analyse the order that every member in the climate-impact ensemble holds in the annual ranking corresponding to every site and cropping option. The frequency of appearance of each ensemble member in the first, middle and end positions in the ranking was also studied.

The same analysis was done using the CC impact or yield change projected by each ensemble member. The difference (in \%) in crop mean yields between the present and the future climate $(\Delta$ of impacts) was obtained. With these data, a ranking was performed for each site and cropping option, in which ensemble members were sorted based on the $\Delta$ value obtained. The study of these rankings revealed which ensemble members projected a higher or lower impact on crop yields for the IP. The consistency of the climate-impact ensemble was also evaluated using the Kendall's $\tau$ for different wheat cropping options in the different sites. A concordant pair of 2 cropping options $\left(i, i^{\prime}\right)$ was one meeting the following formula:

$$
\operatorname{sgn}\left(\Delta_{i, j, h_{2}}-\Delta_{i, j, h_{1}}\right)=\operatorname{sgn}\left(\Delta_{i^{\prime}, j, h_{2}}-\Delta_{i^{\prime}, j, h_{1}}\right)
$$

and discordant pairs were those meeting these criteria:

$$
\operatorname{sgn}\left(\Delta_{i, j, h_{2}}-\Delta_{i, j, h_{1}}\right)=-\operatorname{sgn}\left(\Delta_{i^{\prime}, j, h_{2}}-\Delta_{i^{\prime}, j, h_{1}}\right)
$$

where $\Delta$ denotes the yield difference (in \%) between the control period and future climate; $i$ denotes the cropping option $(1 \ldots 5) ; j$ is the site $(1 \ldots 12)$; and $h$ is the RCM (1...10). The comparisons were made keeping $j$ constant for 2 different wheat cropping options. Thus, consistency of RCMs was measured both in terms of absolute yield rankings and the magnitude of yield changes projected for CC.

\section{RESULTS AND DISCUSSION}

\subsection{Changes in potential yields}

The percentage variation in potential yields between the periods 1961-1990 and 2071-2100 in the 12 study sites is shown in Table 2, which summarises the impact of the projections analysed in this work. All ensemble models and years are used in the comparisons between both periods. In the case of winter wheat, both for rainfed and irrigated conditions, simulations in southern Spain were not included since this crop is currently not sown there because vernalisation requirements are not fulfilled.

These impacts were widely discussed in Mínguez et al. (2007) and Ruiz-Ramos \& Mínguez (2010), and briefly, showed that maize would be the crop most affected by $\mathrm{CC}$ in the Peninsula, with a reduced yield in all the study sites except for the NW-Coast, NWInland and NE (all these sites are in northern areas). This was due to the shortening of the cycle's duration that was not compensated for by the increase in photosynthetic rates under higher $\left[\mathrm{CO}_{2}\right]$. Yield variability was greater in the future climate (30 out of 48 instances), but this rate was reduced (16 out of 30) when simulations under irrigation were considered. 
Table 2. Variation in potential yield ( $\Delta$ in \%): comparison of yield data from the ensemble (mean of 10 members) between the control period (289 data for maize for each site, 287 for wheat) and future climate (280 data for each site). ${ }^{*} \mathrm{p} \leq 0.05{ }_{i}{ }^{* *} \mathrm{p} \leq 0.01$

\begin{tabular}{|c|c|c|c|c|c|c|c|c|c|c|c|c|}
\hline Cropping option & $\begin{array}{l}\text { NW- } \\
\text { Coast }\end{array}$ & $\begin{array}{l}\text { NW- } \\
\text { Inland }\end{array}$ & NE & $\begin{array}{l}\text { NE- } \\
\text { Valley }\end{array}$ & $\begin{array}{c}\mathrm{N}- \\
\text { Plateau }\end{array}$ & Centre & $\begin{array}{c}\text { S- } \\
\text { Plateau } 1\end{array}$ & $\begin{array}{c}\text { S- } \\
\text { Plateau } 2\end{array}$ & $\begin{array}{l}\text { SW- } \\
\text { Inland }\end{array}$ & $\begin{array}{l}\text { SE- } \\
\text { Coast }\end{array}$ & $\begin{array}{c}\text { S- } \\
\text { Valley } 1\end{array}$ & $\begin{array}{c}\text { S- } \\
\text { Valley } 2\end{array}$ \\
\hline Maize & $7.3^{* *}$ & $18.5^{* *}$ & $13.1^{* *}$ & $-25.6^{* *}$ & $-19.9^{* *}$ & $-25.8^{* *}$ & $-25.9^{* *}$ & $-21.8^{* *}$ & $-25^{* *}$ & $-8.6^{* *}$ & $-16.1^{* *}$ & $-15.2^{* *}$ \\
\hline Rainfed spring wheat & $-27^{* *}$ & $-24^{* *}$ & $16.4^{* *}$ & $57.2^{* *}$ & $57.1^{* *}$ & $71.1^{* *}$ & $87.8^{* *}$ & $59.4^{* *}$ & $56.5^{* *}$ & $48.1^{* *}$ & $42.2^{* *}$ & $78.7^{* *}$ \\
\hline Rainfed winter wheat & 5.7 & $19.8^{* *}$ & $35.3^{* *}$ & -9.7 & $13.5^{*}$ & $-15.3^{*}$ & & & & & & \\
\hline Irrigated spring wheat & $-19.5^{* *}$ & $-27.1^{* *}$ & $-12^{* *}$ & 0.1 & -2.6 & -1.5 & $-5.3^{* *}$ & $6.7^{* *}$ & -3.7 & 3.6 & 0.6 & 2.6 \\
\hline Irrigated winter wheat & $58.7^{* *}$ & $33.7^{* *}$ & $31.1^{* *}$ & $21^{* *}$ & $20.7^{* *}$ & $16.5^{* *}$ & & & & & & \\
\hline
\end{tabular}

\subsection{Uncertainty related to differences between RCMs}

\subsubsection{Ensemble internal consistency depending on cropping option and site}

The results of the comparison between rankings of yield projections (Tables $3 \& 4$ ) correspond to each site and wheat cropping option combination. Since there are 4 cropping options (RSW: rainfed spring wheat); RWW: rainfed winter wheat); ISW: irrigated spring wheat); IWW: irrigated winter wheat), there are 6 possible comparisons. Table 3 includes the results for the current climate (1961-1990). Each of the 6 cropping comparisons includes $29 \mathrm{yr}$, and a Kendall's $\tau$ was obtained for each year; however, the table only reports the number of $\tau$ s that are statistically significant ( $p<0.1$ ) out of 29 , as well as the minimum and maximum among those that are significant. Cells were left blank in Tables $3 \& 4$ for some locations where rank comparisons were not possible because one element of the pair was not applicable. For instance, only the pair RSW - ISW was relevant in all 6 southern locations in Table 3 (S-Plateau 2, SW-Inland, S-Valley 1, S-Valley 2, S-Plateau 1, SECoast) because winter wheat is not sown in the south of the IP.

The comparison RSW - RWW shown in the first row in both panels, reveals that there are many years with significant $\tau$ s for some sites. For example, the $\tau \mathrm{s}$ were statistically significant in 29 out of 29 comparisons in the N-Plateau, and among the 29, the minimum was 0.6 and the maximum was 1 . This means that the ranking of RCMs are very similar for RSW and RWW.

In general, the highest rank consistencies were achieved when rainfed cropping or irrigated cropping options were compared (rows 1 and 6 in each panel). Rank comparisons of rainfed with irrigated cropping options (rows 2 through 6 ) were much less consistent. This shows that RCMs exhibit more consistency among projections with the same crop but a different management option than among simulations with different crops. From the comparison of RSW, RWW and ISW, a number of significant $\tau$ s were obtained $(p<0.1)$. In the future period $(2071-2100$, Table 4), if we compared RSW and ISW, there were 28 significant $\tau \mathrm{s}$ in the NW-Coast, 26 in the NWinland, and 23 in the NE. In the present climate, there were also 29 in the NW-Coast and 15 in S-Valley 2. In general, the consistency of the rankings of RCMs for future climate (Table 4) was lower than for the period 1961-1990. For rainfed wheat, the consistency remained high, but lower than for the current climate.

This highlights the difficulty in simulating the large spatial variability of rainfall in A2, in agreement with Giorgi et al. (2004) and Sánchez et al. (2004). The ranking consistency was higher between RSW and the same cropping option with irrigation, for future climate in the NW-Coast (28 out of 29 instances), NW-Inland (26 out of 29) and NE (23 out of 29). In these areas, the effects of water shortage under rainfed conditions were likely smaller (smaller decrease in precipitation; Giorgi et al. 2004, Christensen \& Christensen 2007), therefore, the difference between the responses of rainfed and irrigated cropping options was also smaller.

In maize, the number of significant cases $(p<0.1)$ was much lower than for wheat (results not reported). Moreover, $\tau$ reached negative values in many instances, indicating that the rankings of RCMs were arranged in the reverse way when 2 sites were compared. These results point to a different seasonal response of RCM rankings and therefore, ensemble inconsistency.

Rankings of RCMs (i.e. rankings of yield projections driven by each RCM data) were also used to analyse the positions held by the members of the ensemble, in order to investigate the spatial consistency of the ensemble. Comparing rankings of RCMs between 2 sites and the same cropping option (Table 5 ), we found that $\tau$ s were often positive for ISW and 


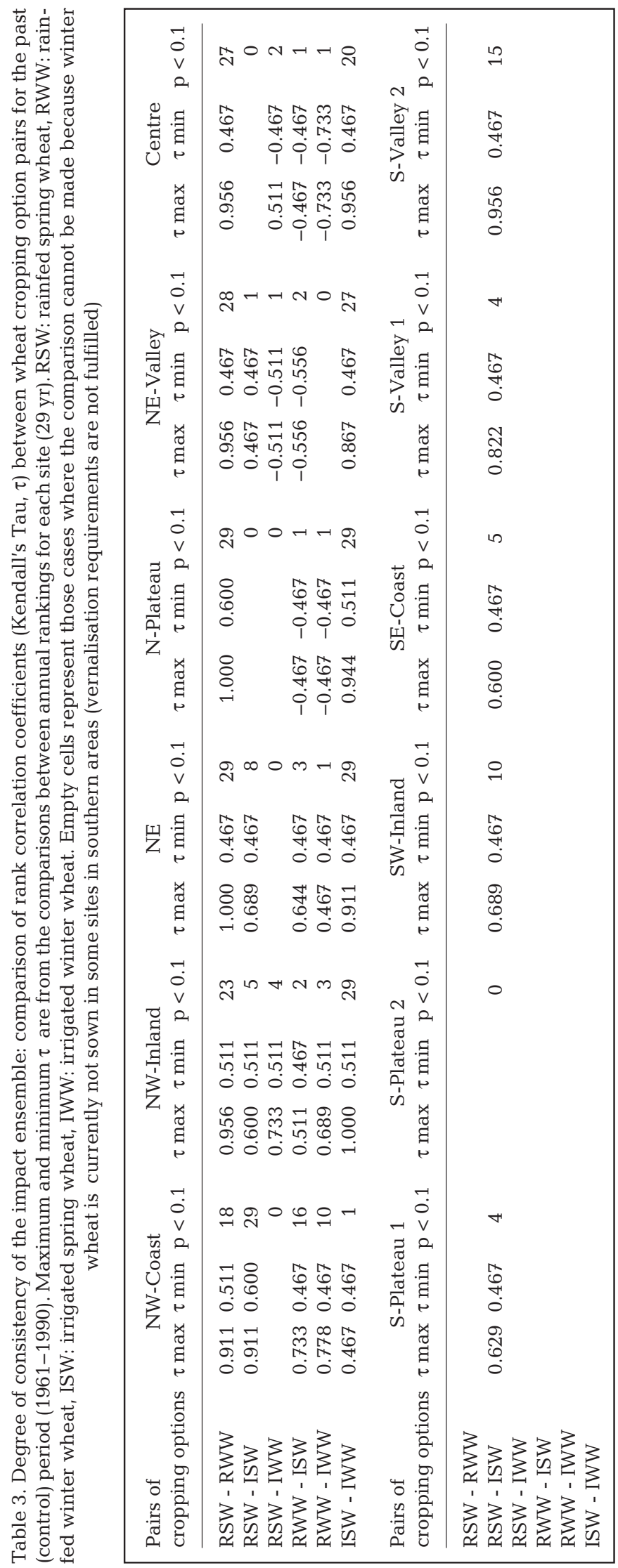

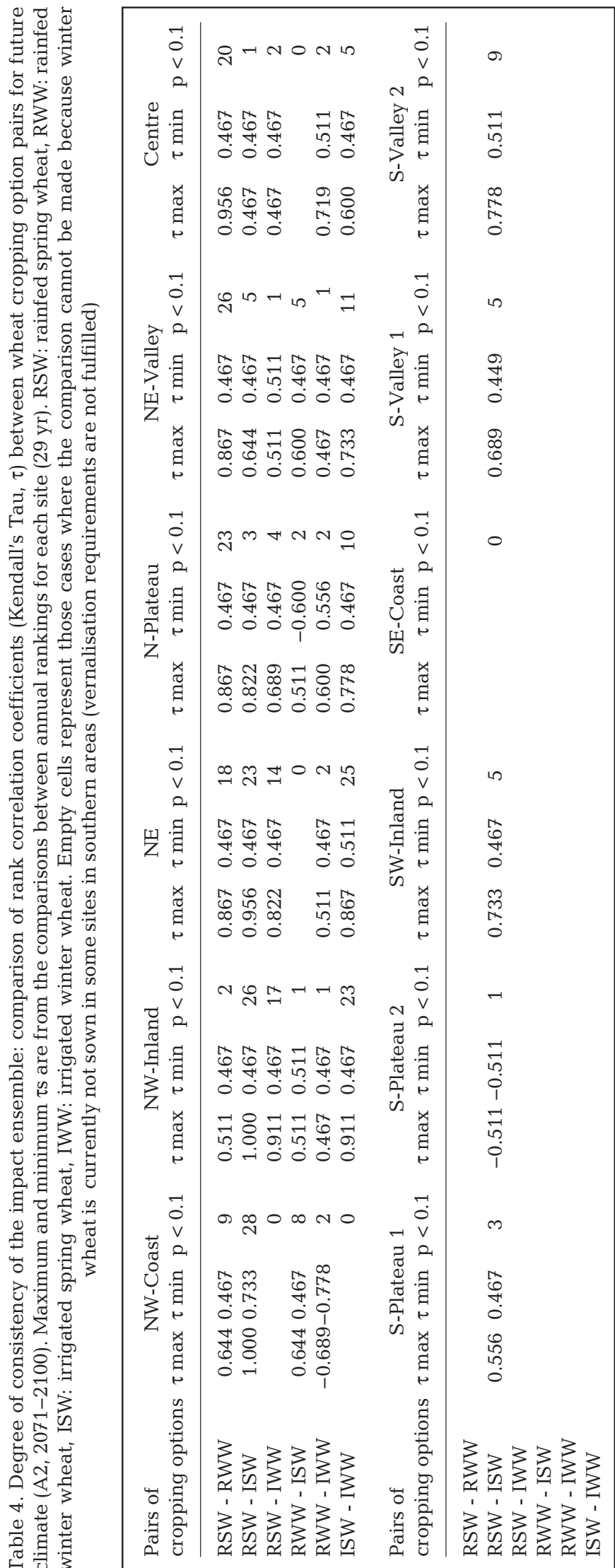




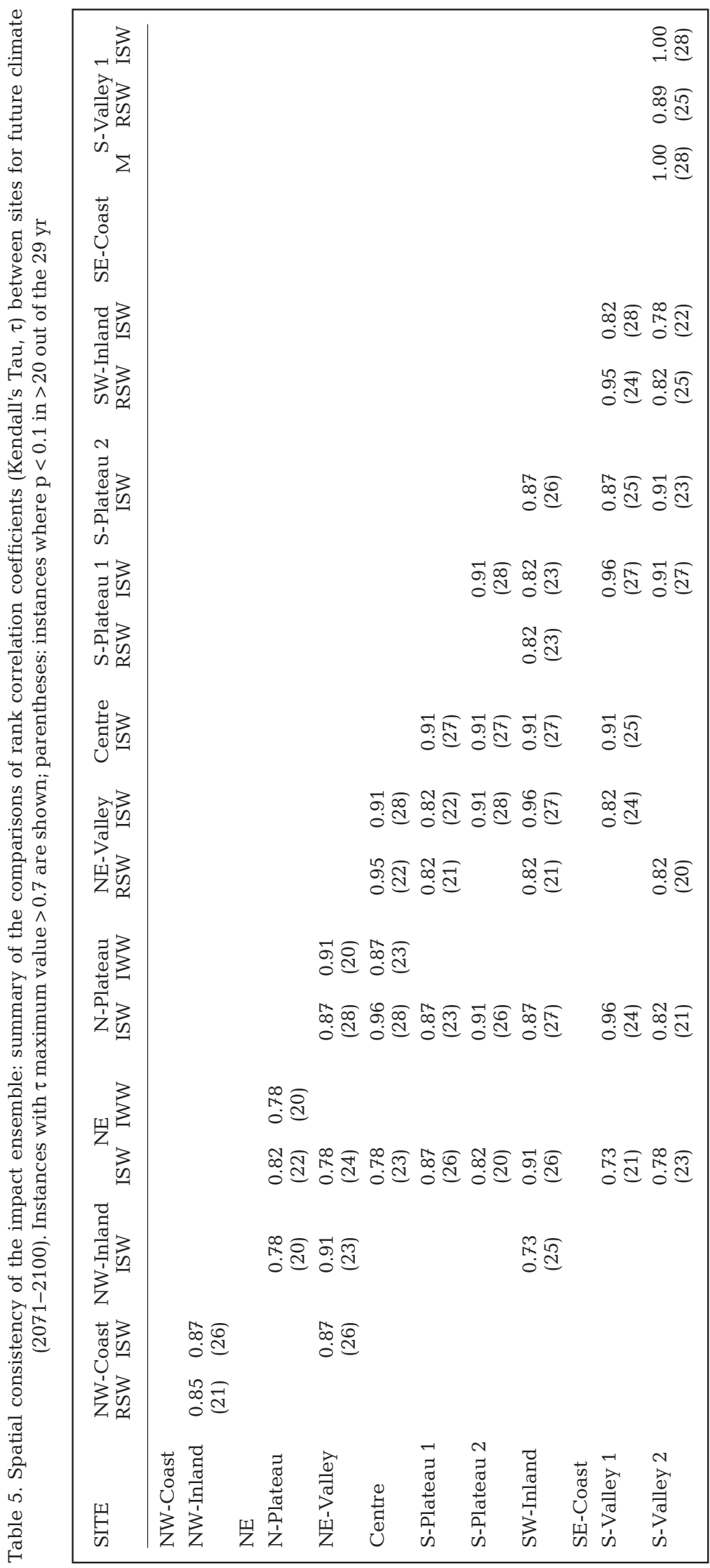

RSW, pointing to a positive relation between rankings of RCMs. The SE-Coast was the site in which RCMs differed the most for all cropping options as regards the arrangement of models depending on their yield (the ocean influence of the climate data could be related to this result). ISW was the cropping option which achieved the greatest correspondence for the rankings of different sites, with a large number of significant instances $(p<0.1$ in many cases) for all comparisons and $\tau$ s (close to 1 in many cases, for both periods). This was also the cropping option that best avoided eventual limitations of water stress (as opposed to rainfed), crop duration (as opposed to maize), and vernalisation requirements (as opposed to winter wheat); and the results were coherent with this. Differences among ensemble members were maintained constant across sites as shown by the greater correspondence in rankings of different sites for ISW. Nevertheless, this cropping option showed the greatest uncertainty in the analyses carried out by Ruiz-Ramos \& Mínguez (2010), where reducing uncertainty of projections was highlighted as a priority for this reference crop. This new finding may help identify causes of its greater uncertainty because the ensemble presents greater differences among members that do not depend on site.

Table 6 shows $\tau$ values from the analyses of consistency of the ensemble applied to the change in crop yield, analysing the rankings of impacts by means of $\Delta \mathrm{s}$. Comparisons were made between rankings for 2 wheat cropping options in each site. $\tau$ values were low for most sites, and negative in a lot of cases. This means that the consistency of the rankings is generally low, so ensemble members do not arrange in a similar way for the different wheat cropping options. Also, there were only 10 significant cases $(p<0.1)$ out of the 42 comparisons made. The highest values of $\tau$ were those resulting from the comparison between RSW and ISW in the NW-Coast (0.822) and NW-Inland (0.733), so the correspondence between the rankings was higher in these cases.

Fig. 2 shows the yield variations ( $\Delta$, in \%) between the present and the future climate 
Table 6. Degree of consistency of the impact ensemble: comparison of rank correlation coefficients (Kendall's Tau, $\tau$ ) for delta rankings between wheat cropping options pairs. Bold: significant

\begin{tabular}{|c|c|c|c|c|c|c|c|c|c|c|c|c|}
\hline \multirow{2}{*}{$\begin{array}{l}\text { Pair of } \\
\text { cropping options }\end{array}$} & \multicolumn{2}{|c|}{ NW-Coast } & \multicolumn{2}{|c|}{ NW-Inland } & \multicolumn{2}{|c|}{ NE } & \multicolumn{2}{|c|}{ N-Plateau } & \multicolumn{2}{|c|}{ NE-Valley } & \multicolumn{2}{|c|}{ Centre } \\
\hline & $\tau$ & $\mathrm{p}$ & $\tau$ & $\mathrm{p}$ & $\tau$ & $\mathrm{p}$ & $\tau$ & $\mathrm{p}$ & $\tau$ & $\mathrm{p}$ & $\tau$ & $\mathrm{p}$ \\
\hline RSW - RWW & -0.422 & 0.107 & -0.244 & 0.371 & -0.022 & 1.000 & 0.511 & 0.049 & 0.689 & 0.007 & 0.244 & 0.371 \\
\hline RSW - ISW & 0.822 & 0.001 & 0.733 & 0.004 & 0.467 & 0.074 & -0.289 & 0.283 & -0.467 & 0.074 & -0.244 & 0.371 \\
\hline RSW - IWW & 0.111 & 0.721 & -0.289 & 0.283 & -0.244 & 0.371 & -0.200 & 0.474 & -0.333 & 0.210 & -0.111 & 0.720 \\
\hline RWW - ISW & -0.511 & 0.049 & -0.156 & 0.591 & -0.467 & 0.074 & -0.422 & 0.107 & -0.155 & 0.591 & -0.111 & 0.720 \\
\hline RWW - IWW & 0.111 & 0.721 & 0.600 & 0.020 & -0.022 & 1.000 & 0.200 & 0.474 & -0.111 & 0.720 & 0.556 & 0.032 \\
\hline ISW - IWW & 0.111 & 0.721 & -0.200 & 0.474 & -0.156 & 0.591 & 0.111 & 0.720 & 0.244 & 0.371 & -0.111 & 0.720 \\
\hline Pair of & \multicolumn{2}{|c|}{ S-Plateau 1} & \multicolumn{2}{|c|}{ S-Plateau 2} & \multicolumn{2}{|c|}{ SW-Inland } & \multicolumn{2}{|c|}{ SE-Coast } & \multicolumn{2}{|c|}{ S-Valley 1} & \multicolumn{2}{|c|}{ S-Valley 2} \\
\hline cropping options & $\tau$ & $\mathrm{p}$ & $\tau$ & $\mathrm{p}$ & $\tau$ & $\mathrm{p}$ & $\tau$ & $\mathrm{p}$ & $\tau$ & $\mathrm{p}$ & $\tau$ & $\mathrm{p}$ \\
\hline $\begin{array}{l}\text { RSW - RWW } \\
\text { RSW - ISW } \\
\text { RSW - IWW } \\
\text { RWW - ISW } \\
\text { RWW - IWW } \\
\text { ISW - IWW }\end{array}$ & -0.067 & 0.858 & 0.289 & 0.283 & 0.155 & 0.591 & 0.289 & 0.283 & 0.022 & 1.000 & 0.378 & 0.152 \\
\hline
\end{tabular}

in each site under study for 2 different cropping options, as projected by each ensemble member. A great variability in the impact projected by the 10 ensemble members is shown.

\subsubsection{Behaviour of individual RCMs applied to the IP}

For a given site and cropping option, the 3 members of the ensemble that most frequently appeared in the 3 first positions in the annual RCM rankings were chosen for the study of the rankings. The same was done for those occurring most frequently at intermediate positions, and also at the end positions (Table 7).

Table 7 shows the number of sites where each member of the ensemble of yield projections appeared at a specific rank with a higher frequency. Thus, for example, in the present climate, the ensemble member obtained with ARPEGE data (in 9 out of the 12 sites) along with HadRM3P (in 7 out of the 12 sites) were the ensemble members providing lower maize yields and standing in the lowest ranking positions. For the same period, PROMES and RCAO were in the highest ranking positions in 6 out of the 12 sites under study. For the future climate, RACMO and CLM were in intermediate positions in most of the sites. The projections resulting from PROMES were lowest in the ranking for all the sites under study, both for rainfed and irrigated wheat cropping options. This contrasts with the case of maize, highlighting a different response of PROMES for winter and summer projections. Under rainfed conditions,
ARPEGE were in the upper positions in most sites (except for N-Plateau and NW-Inland) for both periods. RegCM was also found among the first positions, except for the NW-Coast.

As with spring wheat, PROMES was in the lowest ranking positions in most sites for winter wheat. Under rainfed conditions, the highest yields were obtained with the model ARPEGE in 5 out of the 6 sites. Nevertheless, irrigated cropping options did not show a clear trend. Results given by REMO were at intermediate positions both for RWW IWW cropping options for most sites; projections obtained with RegCM were first in rainfed and irrigated wheat cropping options, except for the NE-Valley. (See Appendix Tables A1-A3 for further information).

The ranges of variation in temperature, precipitation and crop yield projected for Spain by the ensemble members are very wide. Ranges for mean temperature and precipitation changes span 2 to $4^{\circ} \mathrm{C}$ in winter and 4 to $7^{\circ} \mathrm{C}$ in summer, and -50 to $+10 \%$ in winter and -50 to $-25 \%$ in summer, respectively. All crop yields vary from -50 to $+100 \%$ (Mínguez et al. 2007). These large ranges make direct interpretation of results difficult. Table 8 shows qualitative information on the main differences found in simulated climate and crop yield changes. This table was built by combining the interpretation of our own work with the results shown in Christensen \& Christensen (2007), Déqué et al. (2007) and Jacob et al. (2007). It attempts to explain the behaviour of each member of the ensemble as regards their yield projections and impacts. The projections on rainfall variation in the future climate did not affect the estimated yields for 


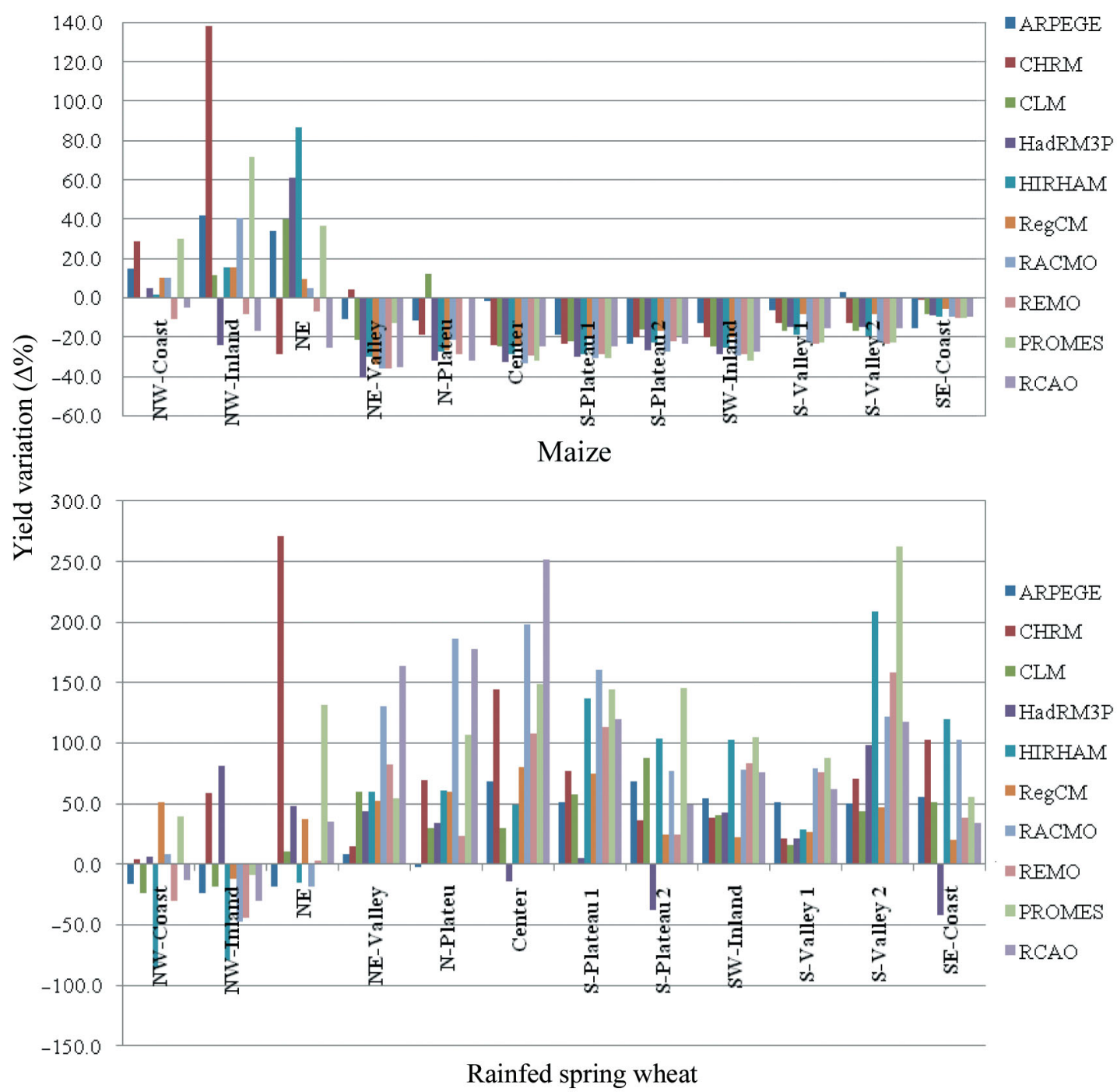

Fig. 2. Yield variation ( $\Delta$ in $\%$ ) in maize and rainfed spring wheat between the current and future climate. $\Delta$ s are projected for each site by each ensemble member

irrigated cropping options; therefore, the evolution of temperature bore a greater influence on the yield projections for 2071-2100 in these instances. Coherence of climate, yield and impact projections was analysed as shown in Table 8, which offers a qualitative assessment of whether RCMs projecting warmer temperatures and greater precipitation decreases lead to greater relative yield decreases.

The coherence level expresses whether agronomic projections are related to temperature and precipitation projections. For instance, the decrease in yield in an irrigated crop grown during summer should not be very large if warming is low (irrespective of the precipitation change, because irrigation compensates for this). It is a qualitative assessment based on 2 variables (temperature and precipitation projec- tions): if there is coherence in temperature and precipitation changes with yield change, then coherence level is characterised as high; if there is coherence only in temperature or precipitation, then coherence is moderate; and finally, if there is no coherence in either temperature or precipitation, coherence is low. The last case may point to the existence of other factors driving the impact, which may not have been considered here, e.g. extreme events.

In the case of ARPEGE, rainfed crops were less affected by water stress because projections in rainfall do not diminish markedly and temperatures do not increase as in other RCMs. For CHRM, lower warming projections might lessen yield decrease for irrigated crops, so this member projects higher yields for irrigated crops, while a great drop in rainfall 
Table 7. Ranking analyses results showing ensemble members which most frequently appeared in the first positions of the ranking (rank $<4$ ), in the middle positions $(4 \leq$ rank $\leq 7)$ and in the last positions (rank $>7$ ) among all possible sites. Parentheses: number of sites in which the ensemble member appeared in that position for each cropping option

\begin{tabular}{|c|c|c|c|c|c|}
\hline $\begin{array}{l}\text { Cropping } \\
\text { option }\end{array}$ & Period & $\begin{array}{l}\text { No. } \\
\text { sites }\end{array}$ & Rank $<4$ & $4 \leq$ Rank $\leq 7$ & Rank $>7$ \\
\hline Maize & $\begin{array}{l}\text { Control } \\
\text { A2 }\end{array}$ & $\begin{array}{l}12 \\
12\end{array}$ & $\begin{array}{c}\text { PROMES (6), } \\
\text { RCAO (6) } \\
\text { RegCM (8), CHRM (7), } \\
\text { PROMES (7) }\end{array}$ & $\begin{array}{c}\text { RACMO (8) } \\
\text { RACMO (8), CLM (7) }\end{array}$ & $\begin{array}{c}\text { ARPEGE (9), } \\
\text { HadRM3P (7) } \\
\text { REMO (10), HadRM3P (7) }\end{array}$ \\
\hline \multirow[t]{2}{*}{$\begin{array}{l}\text { Rainfed } \\
\text { spring wheat }\end{array}$} & Control & 12 & $\begin{array}{l}\text { RegCM (11), ARPEGE (10), } \\
\text { CLM (8) }\end{array}$ & RCAO (9) & PROMES (12), REMO (7) \\
\hline & A2 & 12 & $\begin{array}{c}\text { RegCM (11), ARPEGE (9), } \\
\text { CLM (7) }\end{array}$ & HIRHAM (9), RCAO (8) & PROMES (11), HadRM3P (8) \\
\hline \multirow[t]{2}{*}{$\begin{array}{l}\text { Irrigated } \\
\text { spring wheat }\end{array}$} & Control & 12 & $\begin{array}{c}\text { RegCM (11), CHRM (9), } \\
\text { HadRM3P (7) }\end{array}$ & RACMO (7) & $\begin{array}{c}\text { PROMES (12), CLM (7), } \\
\text { REMO (7) }\end{array}$ \\
\hline & A2 & 12 & $\begin{array}{c}\text { RegCM (11), HadRM3P (10), } \\
\text { CHRM (7) }\end{array}$ & $\begin{array}{l}\text { CLM (11), RCAO (9), } \\
\text { RACMO (7) }\end{array}$ & $\begin{array}{l}\text { PROMES (12), REMO (9), } \\
\text { HIRHAM (7) }\end{array}$ \\
\hline Rainfed & Control & 6 & ARPEGE (5), RegCM (5) & REMO (5) & PROMES (6), CHRM (4) \\
\hline winter wheat ${ }^{1}$ & A2 & 6 & $\begin{array}{c}\text { ARPEGE (5), RegCM (5), } \\
\text { CLM (4) }\end{array}$ & RCAO (6), REMO (5) & $\begin{array}{l}\text { CHRM (5), HadRM3P (4), } \\
\text { PROMES (4) }\end{array}$ \\
\hline \multirow[t]{2}{*}{$\begin{array}{l}\text { Irrigated } \\
\text { winter wheat }\end{array}$} & Control & 6 & $\begin{array}{c}\text { CHRM (5), RegCM (5), } \\
\text { RCAO (4) }\end{array}$ & HIRHAM (5), REMO (5) & CLM (6), PROMES (6) \\
\hline & A2 & 6 & $\begin{array}{c}\text { HadRM3P (5), RegCM (5), } \\
\text { CHRM (4) }\end{array}$ & REMO (5), HIRHAM (4) & PROMES (5), CLM (4) \\
\hline
\end{tabular}

would decrease rainfed yields. Similar to ARPEGE, CHRM is in the first positions of the ranking for the yield impact on maize. For CLM, a smaller rise in temperatures reduced the increase of evapotranspiration (ET) in crops, favouring yield in rainfed conditions, but the coherence across crops and sites was only moderate. For HadRM3P, irrigated winter crops were favoured by milder winters, but rainfed ones were affected by a decrease in rainfall. Maize was affected by high spring and summer warming. For HIRHAM, coherence was moderate and clear trends were found only in summer when irrigation excluded precipitation from the analysis. For RegCM, smaller decreases in rainfall favoured rainfed crops, and milder warming also favoured irrigated cropping options. For RACMO, higher warming and rainfall decrease should have been translated into lower yield for all crops, but this was not the case, with impact being close to the ensemble mean. This result points to other factors driving the final impact, e.g. the frequency or intensity of extreme values of maximum temperature and water deficit periods, which are not addressed here. RACMO was also the RCM showing the lowest coherence in the IP. For REMO, winter wheat benefited from milder winter temperatures because of its longer crop growth duration cycle as compared to spring wheat; this longer cycle could have compensated for the shortening of its crop duration due to warming. This was not the case for the other cropping options. For PROMES, the results were coherent for winter cropping options but not for maize, suggesting that other factors (e.g. extreme values as mentioned for RACMO) were driving the summer impacts. For RCAO, the values of warming temperatures, which were close to the ensemble mean, were driving yield projections, which were also close to the mean of the impact ensemble.

Impact projections evidenced the differences among the RCMs and permitted assessment of their existing variability and coherence. Five out of 10 ensemble members showed high coherence across cropping options and sites, and only one showed low coherence. This can be related to the 'climate sensitivity' of the RCMs that make up the ensemble, since some of the members can be particularly sensitive to a rise in temperature or a change in rainfall (Christensen \& Christensen 2007). However, for some RCMs, other factors need to be considered to explain climate and impact projections, as it was shown for the PROMES and RACMO models. Thus, the analysis shown here constitute a feedback for climate modelers, enhancing differences among RCMs through impact responses which help to isolate or quantify partial aspects of climate. 
Table 8. Analysis of the coherence between projections of temperature and rainfall changes, and yields and yield changes projected by ensemble members for the Iberian Peninsula under control and A2 scenarios

\begin{tabular}{|c|c|c|c|c|c|}
\hline Ensemble member & Temperature change & Rainfall change & Yield & Yield change & Coherence level \\
\hline ARPEGE & $\begin{array}{l}\text { RCM with the lowest } \\
\text { warming estimate in } \\
\text { summer. }\end{array}$ & $\begin{array}{l}\text { Smaller decreases } \\
\text { than the rest of } \\
\text { RCMs in spring and } \\
\text { in winter, along with } \\
\text { RegCM and RCAO. }\end{array}$ & $\begin{array}{l}\text { Greater yield values } \\
\text { than the rest of } \\
\text { RCMs for rainfed } \\
\text { wheat. }\end{array}$ & $\begin{array}{l}\text { In the first } 3 \text { rank } \\
\text { positions for maize for } \\
\text { most sites. }\end{array}$ & $\mathrm{HIGH}$ \\
\hline CHRM & $\begin{array}{l}\text { Lower warming than } \\
\text { most of the RCMs, } \\
\text { especially in winter. }\end{array}$ & $\begin{array}{l}\text { Highest drop in all } \\
\text { seasons. Along with } \\
\text { HadRM3P, highest } \\
\text { drop in winter. }\end{array}$ & $\begin{array}{l}\text { Greater yields than } \\
\text { the rest of RCMs for } \\
\text { irrigated crops. }\end{array}$ & $\begin{array}{l}\text { The fifth rank position } \\
\text { and above for maize. } \\
\text { Last position for } \\
\text { irrigated winter wheat. }\end{array}$ & $\mathrm{HIGH}$ \\
\hline CLM & $\begin{array}{l}\text { Similar to CHRM. } \\
\text { Lower warming than } \\
\text { most of the RCMs, } \\
\text { especially in spring } \\
\text { and autumn. }\end{array}$ & $\begin{array}{l}\text { Projections close to } \\
\text { the ensemble mean. }\end{array}$ & $\begin{array}{l}\text { 1st positions in rain- } \\
\text { fed wheat. Inter- } \\
\text { mediate positions in } \\
\text { the ranking for spring } \\
\text { maize and wheat } \\
\text { under irri-gation. End } \\
\text { posi-tions for irri- } \\
\text { gated winter wheat. }\end{array}$ & $\begin{array}{l}\text { The fifth rank position } \\
\text { and above for rainfed } \\
\text { winter wheat and for } \\
\text { maize in most sites. }\end{array}$ & MODERATE \\
\hline HadRM3P & $\begin{array}{l}\text { High warming in } \\
\text { winter, autumn and } \\
\text { spring. }\end{array}$ & $\begin{array}{l}\text { Highest drop in } \\
\text { winter, along with } \\
\text { CHRM. }\end{array}$ & $\begin{array}{l}\text { End positions in the } \\
\text { ranking in rainfed } \\
\text { cropping options and } \\
\text { in maize. 1st } \\
\text { positions for irrigated } \\
\text { wheat. }\end{array}$ & $\begin{array}{l}\text { Last rank positions for } \\
\text { maize and rainfed } \\
\text { winter wheat in most } \\
\text { sites. }\end{array}$ & $\mathrm{HIGH}$ \\
\hline HIRHAM & $\begin{array}{l}\text { Low warming in } \\
\text { summer. }\end{array}$ & $\begin{array}{l}\text { Lowest drop in } \\
\text { spring and in } \\
\text { summer. }\end{array}$ & $\begin{array}{l}\text { Intermediate } \\
\text { positions in the } \\
\text { ranking, except for } \\
\text { irrigated spring } \\
\text { wheat, which takes } \\
\text { the last positions in } \\
\text { many sites. }\end{array}$ & $\begin{array}{l}\text { Medium impacts for } \\
\text { maize and rainfed } \\
\text { winter wheat. }\end{array}$ & MODERATE \\
\hline RegCM & $\begin{array}{l}\text { Low warming in } \\
\text { summer and winter. }\end{array}$ & $\begin{array}{l}\text { A drop usually lower } \\
\text { than the ensemble } \\
\text { mean, especially in } \\
\text { autumn. }\end{array}$ & $\begin{array}{l}1 \text { st positions in the } \\
\text { ranking for all crop } \\
\text { options. }\end{array}$ & $\begin{array}{l}\text { 2nd position for maize } \\
\text { in Plateau and Centre. } \\
\text { Over the fourth rank } \\
\text { position for irrigated } \\
\text { spring wheat. In the last } \\
\text { rank positions for } \\
\text { rainfed winter wheat. }\end{array}$ & HIGH \\
\hline RACMO & $\begin{array}{l}\text { Higher warming than } \\
\text { the ensemble mean in } \\
\text { all seasons. }\end{array}$ & $\begin{array}{l}\text { High drop in all } \\
\text { seasons. }\end{array}$ & $\begin{array}{l}\text { Average values in all } \\
\text { instances. }\end{array}$ & $\begin{array}{l}\text { In the upper part of the } \\
\text { ranking for rainfed } \\
\text { spring wheat in most } \\
\text { sites. Below the 6th rank } \\
\text { position for maize in } \\
\text { most sites. }\end{array}$ & LOW \\
\hline REMO & $\begin{array}{l}\text { High warming } \\
\text { especially in winter. }\end{array}$ & $\begin{array}{l}\text { Close to the ensemble } \\
\text { mean in all seasons, } \\
\text { over the mean in } \\
\text { autumn. }\end{array}$ & $\begin{array}{l}\text { End positions for } \\
\text { spring wheat and } \\
\text { maize. Intermediate } \\
\text { positions for winter } \\
\text { wheat. }\end{array}$ & $\begin{array}{l}\text { Last rank position for } \\
\text { maize and irrigated } \\
\text { wheat (all irrigated } \\
\text { crops) }\end{array}$ & MODERATE \\
\hline PROMES & $\begin{array}{l}\text { Higher warming than } \\
\text { the ensemble mean, } \\
\text { especially in summer. }\end{array}$ & $\begin{array}{l}\text { Lower drops than the } \\
\text { ensemble mean in } \\
\text { spring and summer. }\end{array}$ & $\begin{array}{l}\text { End positions in the } \\
\text { wheat ranking. 1st } \\
\text { positions for maize. }\end{array}$ & $\begin{array}{l}\text { First rank positions for } \\
\text { winter wheat and } \\
\text { rainfed spring wheat. }\end{array}$ & MODERATE \\
\hline $\mathrm{RCAO}$ & $\begin{array}{l}\text { Close to the ensemble } \\
\text { mean. }\end{array}$ & $\begin{array}{l}\text { Lower drops than } \\
\text { the ensemble mean } \\
\text { in winter. }\end{array}$ & Average values. & $\begin{array}{l}\text { Intermediate rank } \\
\text { positions for irrigated } \\
\text { spring wheat. }\end{array}$ & HIGH \\
\hline
\end{tabular}




\subsection{Adaptation: a summer crop becoming a winter-sown crop}

The adaptation strategy identified for maize consisted of a change in variety and an earlier sowing date of $\sim 2.5 \mathrm{mo}$. The adapted variety (PRUAD1) has longer growth duration, and is particularly different in having a lesser photoperiod sensitivity, a longer thermal period for leaf appearance, and mainly a longer grain filling duration. Kernel growth and cob kernel number are the same. Characteristics of crop varieties such as the above are described through 'genetic coefficients' in CERES models. Genetic coefficients of PRUAD1 and those of the variety used in the impact simulations (PRU001) are presented in Table 9. PRU001 has a cycle equivalent to an FAO 700 cycle (this term refers to the classification of maize varieties adopted by the FAO. Hybrids are classified in 9 classes from 100 to 900 from shorter to longer crop cycle; López-Bellido 1991) while PRUAD1 has a longer cycle. PRUAD1 is an ideotype (i.e. a feasible target cultivar or plant type) proposed to orient breeding or selection programmes.

Fig. 3 shows the percentage variation in maize yield between both periods (1961-1990 and 2071$2100)$, with and without the above-mentioned adaptation. In sites where yield already increased, adaptation brought a further increase. Moreover, in sites where a drop in yield was projected as a result of CC, adaptation diminished the yield decrease. The adaptations described bring forward the sowing date, so the crop will grow in a period with more favourable temperatures period, increasing the duration of the
Table 9. Genetic coefficients for representative maize varieties used for impact (PRU001) and adaptation simulations (PRUAD1) in the CERES-maize model. ECO no.: cultivar code; P1: thermal time from emergence to the end juvenile phase (degree days above a base temperature of $8^{\circ} \mathrm{C}$ ); P2: development delay (expressed in days) due to photoperiod; P5: thermal time from silking ( $\approx$ flowering) to physiological maturity (degree days above a base temperature of $8^{\circ} \mathrm{C}$ ); G2: maximum number of kernels per plant; G3 is kernel filling rate during the linear grain filling stage under optimum conditions $\left(\mathrm{mg} \mathrm{d}^{-1}\right)$; PHINT: phylochron interval (thermal time between between successive leaf tip appearances, in degree days)

\begin{tabular}{lccccccc} 
Variety & ECO no. & P1 & P2 & P5 & G2 & G3 & PHINT \\
\hline PRU001 CYCLE 700 & PRU001 & 220 & 0.52 & 910 & 700 & 7 & 38.9 \\
PRUAD1 LONG & IB0001 & 320 & 0.3 & 940 & 700 & 7 & 45 \\
SEASON AD & & & & & & & \\
\end{tabular}

vegetative phase and, especially, the grain filling period, thus increasing yield. Hence, the change to a variety that is more adapted to future climate conditions diminished negative effects in all instances. The maize yield was higher in all the sites if adaptation strategies were carried out (Table 10), with an increase of $29 \%$ in SW-Inland. The variability in yield was similar in projections without adaptation and only in the NE-Valley area was the variance found to be significantly greater without adaptation.

These results display the benefits of adaptation, which reduced (increased) the negative (positive) effects of $\mathrm{CC}$ on crops. The change in sowing date could necessitate a reorganisation of the cropping system and should be addressed in further studies. Crops sown before maize in traditional crop sequences or rotations may have to change as well, and repercussions will have to be assessed at farm and agricultural system levels. Consequently, seasonal land-

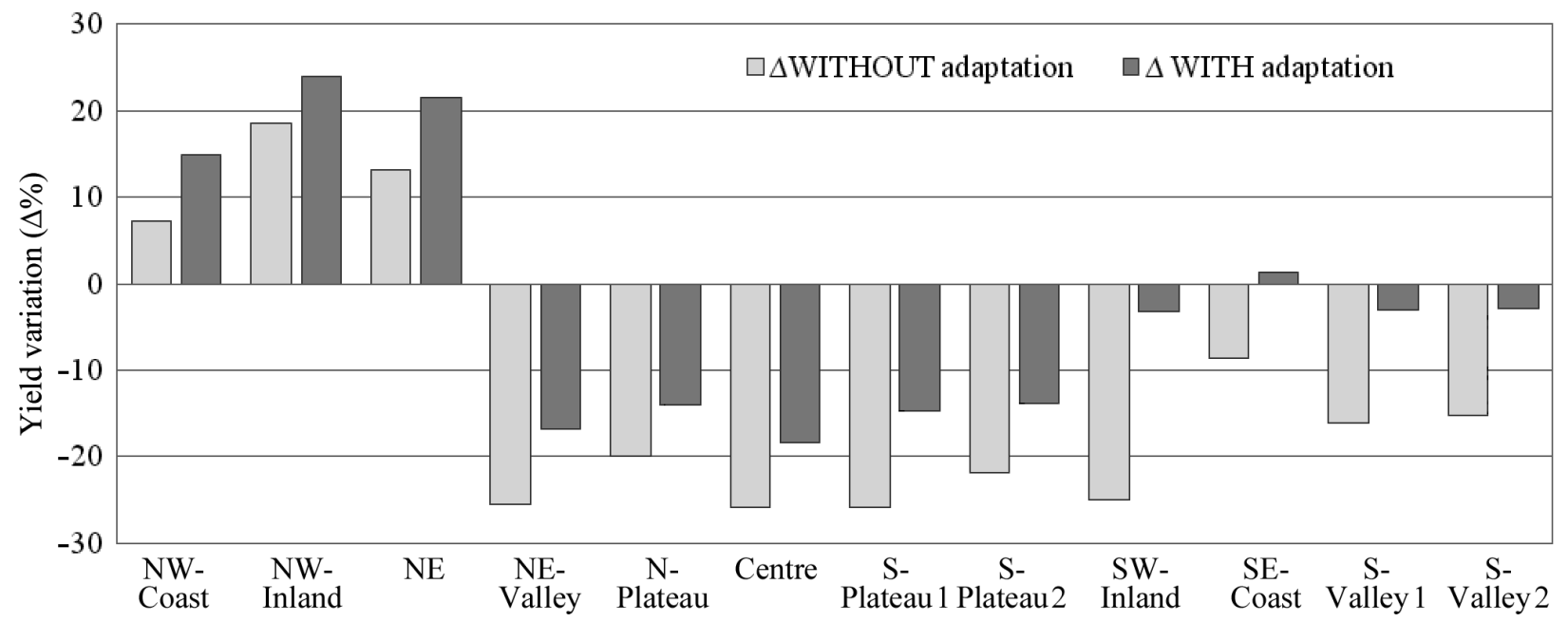

Fig. 3. Yield variation ( $\Delta$ in \%) in maize between the current and future climate: analysis of climate change impacts without and with adaptation 
Table 10. Difference in potential yield between adaptation ('With') and nonadaptation ('Without') during the period 2071-2100 (A2 scenario) in each site ( $\Delta$ in $\%$; 280 cases without adaptation; 279 with adaptation); the variation coefficient (\%) for each case; and the results from the variance comparison test (column shows case with greatest variance). Bold: significant $(\mathrm{p} \leq 0.01)$

\begin{tabular}{|c|c|c|c|c|}
\hline \multirow[t]{2}{*}{ Site } & \multirow[t]{2}{*}{$\Delta$} & \multicolumn{2}{|c|}{ Variation coefficient (\%) } & \multirow{2}{*}{$\begin{array}{l}\text { Variance comparison } \\
\text { test (Levene test) }^{1}\end{array}$} \\
\hline & & Without & With & \\
\hline NW-Coast & 7.1 & 17.48 & 17.36 & With adaptation \\
\hline NW-Inland & 4.7 & 17.73 & 19.78 & With adaptation \\
\hline $\mathrm{NE}$ & 7.6 & 18.41 & 16.86 & Without \\
\hline NE-Valley & 11.9 & 24.51 & 16.73 & Without \\
\hline N-Plateau & 7.4 & 17.53 & 17.02 & With adaptation \\
\hline Centre & 10.0 & 16.76 & 16.08 & With adaptation \\
\hline S-Plateau 1 & 15.2 & 16.45 & 13.62 & Without \\
\hline S-Plateau 2 & 10.2 & 15.91 & 14.02 & Without \\
\hline SW-Inland & 29.1 & 18.85 & 14.90 & With adaptation \\
\hline SE-Coast & 11.0 & 14.26 & 11.94 & Without \\
\hline S-Valley 1 & 15.6 & 17.73 & 15.67 & With adaptation \\
\hline S-Valley 2 & 14.5 & 18.30 & 15.64 & Without \\
\hline
\end{tabular}

guiding adaptation strategies in northern locations (less warm, less arid) than in southern locations.

\section{CONCLUSIONS}

A large amount of work has been invested by the climate science community in recent years to envisage future climate conditions (Projects PRUDENCE, ENSEMBLES at http://ensembles-eu. metoffice.com/, PESETA at http://peseta. jrc.ec.europa.eu/, Moss et al. 2010). These projects represent a significant advance; however, projections are still subject to a high degree of uncertainty in climate. More uncertainty is added when using these climate projections in impact analysis. The current results on the variability of models showed that projections from

Table 11. Degree of consistency of adaptation effects based on rank correlation coefficients (Kendall's Tau, $\tau$ ) of delta $(\Delta)$ rankings for maize with and without adaptation

\begin{tabular}{|lcc|}
\hline Site & $\tau$ & $\mathrm{p}$ \\
\hline NW-Coast & 0.8667 & 0.0007 \\
NW-Inland & 0.9556 & 0.0002 \\
NE & 0.9556 & 0.0002 \\
NE-Valley & 0.6445 & 0.0122 \\
N-Plateau & 0.8222 & 0.0013 \\
Centre & 0.7333 & 0.0042 \\
S-Plateau 1 & 0.3778 & 0.1524 \\
S-Plateau 2 & 0.0222 & 1.0000 \\
SW-Inland & 0.3778 & 0.1524 \\
SE-Coast & -0.1111 & 0.7205 \\
S-Valley 1 & 0.4667 & 0.0736 \\
S-Valley 2 & 0.4222 & 0.1074 \\
\hline
\end{tabular}

scapes will be affected. Adaptation simulations used here were designed to represent potential yield, so the actual benefit is expected to be lower. The adaptation design did not refer to an existing variety, but to a feasible ideotype, to provide clues for crop breeders in developing adapted varieties in the future.

Finally RCM rankings were made for the $\Delta \mathrm{s}$, representing the yield differences between current and future climate. The RCM rankings for the case with no adaptation and the rankings for the crop adaptation scenario were compared using the Kendall $\tau \mathrm{s}$ (Table 11). Values of $\tau$ were high $(>0.7, \mathrm{p}<0.05)$ in the NW, NE and plateau locations, but low and insignificant in all the southern locations. This means that the ensemble performs more predictably in impact-climate ensemble members were very different for the same cropping option and site.

The main components of the variance among the members of the ensemble of climate for the IP are different for each climate variable and season (Dequé et al. 2007). For temperature, most of the variance in winter is explained by the driving GCM, followed by scenario and RCMs in similar percentages. In summer, both scenario and GCM explain similar percentages of the variance. For precipitation, RCM, scenario and GCM explain similar percentages of the variance in winter, while the percentages are slightly larger for GCM and RCM in summer.

In our analysis, we tested the discrepancies among RCMs for only one scenario (A2). Inconsistencies in simulations for irrigated crops would be mainly explained by the driving GCM for the cases when it this GCM is different. When this was not the case, inconsistencies shown here are only explained by the RCM. For rainfed simulations, the GCM influence is smaller because precipitation variance also depends on RCMs. Thus, in this work, the discrepancies shown by ARPEGE and RCAO would be mainly due to the driving GCM for irrigation projections, and to both GCM and RCMs for rainfed projections. For the rest of the ensemble, only the influence of RCMs could be studied, as they shared driving conditions.

Jacob et al. (2007) concluded that the results of the RCMs for today's climate have been carefully validated against independent data sets, mainly the CRU data which made possible their application in many impact studies, including Castro et al. (2007), 
Fronzek \& Carter (2007), Graham et al. (2007), and Halsnæs et al. (2007), among others. However, the consistency with observations is not perfect, and our paper attempts to analyse the consequences of the systematic biases also analysed by Jacob et al. (2007). Moreover, the consistency among RCMs is also far from perfect, so an ensemble of climate models has to be used to consider this uncertainty. This is possible because the signal from the whole PRUDENCE ensemble is significant (Déqué et al. 2007).

The consistency in yield projections that were assessed with the rank correlation coefficient (Kendall's $\tau$ ) was high for spring and winter wheat, both rainfed and irrigated. The sites where consistency was higher were: N-Plateau, NE-Valley, NW-Inland, Centre and NE, in that order. Projections seemed more consistent with one another in the control period than in future climate. The northern half of the IP, where water deficit was smaller, displayed greater consistency, as well as sites with similar climate features. The greatest disparity was found in sites with ocean influence (NW-Coast differed the most from the rest of the study sites). Maize, representing a summer cropping option, showed a different response than wheat, which accounts for the low consistency achieved between both crops, and highlights the different seasonal effects of CC. In particular, the high consistency results for ISW ruled out site as a source of the high uncertainty previously reported by RuizRamos \& Mínguez (2010) for this crop. This is a step further in reducing uncertainty related problems.

The study of the rankings of impacts, i.e. changes in crop yields, revealed that the consistency is low for almost all comparisons made (the rankings of $\Delta \mathrm{s}$ of 2 different wheat cropping options for the same site are not very similar). This analysis established the position of each ensemble member, based on the projected yield for each site and cropping option. RCMs projecting greater future warming in the IP, or a greater decrease in rainfall, were those that generally showed lower yield than the rest of the members of the ensemble. The increase in temperature in the various seasons of the year affected each crop differently because their growth periods were different. $\Delta$ rankings afforded a different set of comparisons among ensemble members, as the analyses looked at projected changes and not absolute crop yields. In general, $\Delta$ rankings are less consistent than rankings based on crop yields. This means that the ensemble's internal consistency is quite low and that uncertainty in crop projections is still considerable. In the 20712100 period, various cropping options showed an increase in yield in most sites when irrigation re- quirements were met (Mínguez et al. 2007, RuizRamos \& Mínguez 2010). Nevertheless, this assumption may not hold in most instances (Bates et al. 2008); therefore, yield increases due to CC could be limited for irrigated crops if water shortages occur. It is thus essential to note that this study is solely based on a yield analysis, with no water or nutrient shortage, nor with diseases or pests.

Some adaptations will be autonomously adopted by farmers, but changes in cropping options that imply seasonal or more drastic changes to traditional cropping patterns may need some support or advice from regional or local governments. Our results are ambiguous with respect to variance comparisons, although adaptation clearly improves yield projections. Rankings of $\Delta \mathrm{s}$ for adaptation effects were systematically more consistent for summer crops in the northern than in the southern locations.

Acknowledgements. This work was financed by the National Plan of the Ministry of Science and Innovation, project MINUNIMAD-CC AGL2008-00385/AGR, and the Regional Plan of the Viceconsejería de Ciencia y Tecnología de Castilla-La Mancha, project PAI08-0009-4676.

\section{LITERATURE CITED}

Ainsworth EA, Long SP (2005) What have we learned from 15 years of free-air $\mathrm{CO}_{2}$ enrichment (FACE)? A metaanalytic review of the responses of photosynthesis, canopy properties and plant production to rising $\mathrm{CO}_{2}$. New Phytol 165:351-372

Bates BC, Kundzewicz ZW, Wu S, Palutikof JP (eds) (2008) Climate change and water. Technical Paper of the Intergovernmental Panel on Climate Change, IPCC Secretariat, Geneva

Castro M, Gallardo C, Jylhä K, Tuomenvirta H (2007) The use of a climate-type classification for assessing climate change effects in Europe from an ensemble of nine regional climate models. Clim Change 81(Supplement 1): 329-341

Christensen JH, Christensen OB (2007) A summary of the PRUDENCE model projections of changes in European climate by the end of this century. Clim Change 81:7-30

> Déqué M, Rowell D, Lüthi D, Giorgi F and others (2007) An intercomparison of regional climate simulations for Europe: assessing uncertainties in model projections. Clim Change 81(S1):53-70

Easterling WE, Aggarwal PK, Batima P, Brander KM and others (2007) Food, fibre and forest products. Climate change 2007: impacts, adaptation and vulnerability. Contribution of Working Group II to the Fourth Assessment Report of the Intergovernmental Panel on Climate Change. Cambridge University Press, Cambridge, p 273-313

European Commission (2008) Climate change: the challenges for agriculture. Available at http://ec.europa.eu/ agriculture/publi/fact/climate_change/2008_en.pdf 
Fronzek S, Carter T (2007) Assessing uncertainties in climate change impacts on resource potential for Europe based on projections from RCMs and GCMs. Clim Change 81:357-371

García M, Viladrich-Grau M (2009) The economic relevance of climate variables in agriculture: the case of Spain. Econ Agrar Recur Nat 9:149-180

> Giorgi F, Bi X, Pal J (2004) Mean, interannual variability and trends in a regional climate change experiment over Europe. II. Climate change scenario (2071-2100). Clim Dyn 23:839-858

Graham LP, Hagemann S, Jaun S, Beniston M (2007) On interpreting hydrological change from regional climate models. PRUDENCE Special Issue, Clim Change 81 (Supplement 1):97-122

Guereña A, Ruiz-Ramos M, Díaz-Ambrona CH, Conde JR, Mínguez MI (2001) Assessment of climate change and agriculture in Spain using climate models. Agron J 93: 237-249

Halsnæs K, Kühl J, Olesen JE (2007) Turning climate change information into economic and health impacts. Clim Change 81:145-162

Hulme M, Conway D, Jones PD, Barrow EM, Jiang T, Turney C (1995) A 1961-90 climatology for Europe for climate change modelling and impacts applications. Int $\mathrm{J}$ Climatol 15:1333-1363

Iglesias A, Medina F (2009) Conclusiones del cambio climático para la agricultura: ¿un problema de hoy o del futuro? Rev Esp Estud Agrosoc Pesq 221:45-70

Iglesias A, Mínguez MI (1995). Perspectives for maize production in Spain under climate change. In: Rosenzweig C, Allen LH Jr, Harper LA, Hollinger SE, Jones JW (eds) Climate change and agriculture: analysis of potential international impacts, Vol 13. Amer Soc Agron, Madison, WI, p 259-273

Iglesias A, Quiroga S (2007) Measuring the risk of climate variability to cereal production at five sites in Spain. Clim Res 34:47-57

Jacob D, Bärring L, Christensen OB, Christensen JH and others (2007) An inter-comparison of regional climate models for Europe: model performance in present-day climate. Clim Change 81:31-52

> Jones JW, Hoogenboom G, Porter CH, Boote KJ and others (2003) The DSSAT cropping system model. Eur J Agron 18:235-265

Kang Y, Khan S, Ma X (2009) Climate change impacts on crop yield, crop water productivity and food security-a review. Prog Nat Sci 19:1665-1674

Lavalle C, Micale F, Houston TD, Camia A and others (2009) Climate change in Europe. 3. Impact on agriculture and forestry: a review. Agron Sustain Dev 29:433-446

López-Bellido L (1991) Cultivos Herbáceos, Vol I. Cereales. Mundi-Prensa, Madrid

López-Cedrón FX, Boote KJ, Ruíz-Nogueira B, Sau F (2005) Testing CERES-Maize versions to estimate maize production in a cool environment. Eur J Agron 23:89-102
Mariscal MJ (1993) Efectos de la fecha de siembra sobre el crecimiento, desarrollo, producción y uso de agua de genotipos de trigo que difieren en necesidades de vernalización. MSc thesis, Universidad de Córdoba

Mínguez MI, Ruiz-Ramos M, Díaz-Ambrona CH, Quemada M (2004) Productivity in agricultural systems under climate change scenarios. Evaluation and adaptation. J Phys 121:269-281

- Mínguez MI, Ruiz-Ramos M, Díaz-Ambrona CH, Quemada M, Sau F (2007) First-order impacts on winter and summer crops assessed with various high-resolution climate models in the Iberian Peninsula. Clim Change 81: 343-355

Moreno JM (2005) Evaluación Preliminar de los Impactos en España por Efecto del Cambio Climático. Centro de Publicaciones, Secretaría General Técnica, Ministerio de Medio Ambiente, Madrid

> Moss RH, Edmons JA, Hibbard KA, Manning MR and others (2010) The next generation of scenarios for climate change research and assessment. Nature 463:747-756

Nakicenovic N, Swart R (eds) (2000) Emissions scenarios. Special Report of the Intergovernmental Panel on Climate Change. Cambridge University Press, Cambridge

OECC (Oficina Española de Cambio Climático) (2006) Plan Nacional de Adaptación al Cambio Climático. Available at www.presidencia.gub.uy/_web/cambio_climatico/Plan_ Nal_Espana.pdf

$>$ Olesen JE, Carter TR, Díaz-Ambrona CH, Fronzek S and others (2007) Uncertainties in projected impacts of climate change on European agriculture and terrestrial ecosystems based on scenarios from regional climate models. Clim Change 81:123-143

PRUDENCE (2005) PRUDENCE final report. Available at http://prudence.dmi.dk/

> Quemada M, Cabrera ML, McCracken DV (1997) Nitrogen released from surface applied cover crop residues: evaluating CERES-N. Agron J 89:723-729

Rebollo J (1993) Calibración y verificación de un modelo de simulación de trigo (Ceres-Wheat) para las condiciones del Valle del Guadalquivir y su aplicación al análisis de estrategias de riego. MSc thesis, Universidad de Córdoba

> Ruiz-Ramos M, Mínguez MI (2010) Evaluating uncertainty in climate change impacts on crop productivity in the Iberian Peninsula. Clim Res 44:69-82

> Sánchez E, Gallardo C, Gaertner MA, Arribas A, Castro M (2004) Future climate extreme events in the Mediterranean simulated by a regional climate model: a first approach. Global Planet Change 44:163-180

Schiermeier Q (2010) The real holes in climatic science. Nature 463:284-287

Tsuji GY, Uehara G, Balas S (eds) (1994) DSSAT Version 3. University of Hawaii, Honolulu

> Tubiello FN, Fischer G (2007) Reducing climate change impacts on agriculture: global and regional effects of mitigation, 2000-2080. Technol Forecast Soc Change 74: 1030-1056 


\section{APPENDIX}

Table A1. Number of sites out of the 12 under study where each member of the ensemble occupies a specific place in the ranking: analyses for maize

\begin{tabular}{lccc|}
\hline RCM & Rank $<4$ & $4 \leq$ Rank $\leq 7$ & Rank $>7$ \\
\hline Control & & & \\
ARPEGE & 0 & 0 & 9 \\
CHRM & 5 & 4 & 3 \\
CLM & 4 & 5 & 3 \\
HadRM3P & 3 & 2 & 7 \\
HIRHAM & 4 & 5 & 2 \\
RegCM & 4 & 5 & 1 \\
RACMO & 4 & 8 & 1 \\
REMO & 0 & 5 & 6 \\
PROMES & 6 & 1 & 3 \\
RCAO & 6 & 1 & 1 \\
& & & \\
A2 & & & 3 \\
ARPEGE & 4 & 1 & 1 \\
CHRM & 7 & 4 & 1 \\
CLM & 3 & 7 & 7 \\
HadRM3P & 0 & 1 & 4 \\
HIRHAM & 3 & 5 & 3 \\
RegCM & 8 & 3 & 2 \\
RACMO & 1 & 8 & 4 \\
REMO & 0 & 2 & \\
PROMES & 7 & 1 & \\
RCAO & 3 & 4 & \\
& & & \\
& & & \\
\hline
\end{tabular}

Table A2. Number of sites out of the 12 under study where each member of the ensemble occupies a specific place in the ranking: analysis for spring wheat

\begin{tabular}{|c|c|c|c|}
\hline RCMs & Rank <4 & $4 \leq$ Rank $\leq 7$ & Rank $>7$ \\
\hline \multicolumn{4}{|l|}{ RAINFED } \\
\hline \multicolumn{4}{|l|}{ Control } \\
\hline ARPEGE & 10 & 0 & 1 \\
\hline CHRM & 1 & 4 & 4 \\
\hline CLM & 8 & 4 & 0 \\
\hline HadRM3P & 1 & 4 & 5 \\
\hline HIRHAM & 3 & 5 & 2 \\
\hline RegCM & 11 & 0 & 1 \\
\hline RACMO & 0 & 6 & 4 \\
\hline REMO & 1 & 4 & 7 \\
\hline PROMES & 0 & 0 & 12 \\
\hline $\mathrm{RCAO}$ & 1 & 9 & 0 \\
\hline \multicolumn{4}{|l|}{ A2 } \\
\hline \multicolumn{4}{|l|}{ Control } \\
\hline ARPEGE & 9 & 0 & 2 \\
\hline CHRM & 2 & 3 & 5 \\
\hline CLM & 7 & 4 & 0 \\
\hline HadRM3P & 3 & 0 & 8 \\
\hline HIRHAM & 0 & 9 & 3 \\
\hline RegCM & 11 & 1 & 0 \\
\hline RACMO & 1 & 5 & 3 \\
\hline REMO & 0 & 5 & 4 \\
\hline PROMES & 0 & 1 & 11 \\
\hline RCAO & 3 & 8 & 0 \\
\hline \multicolumn{4}{|l|}{ IRRIGAT. } \\
\hline \multicolumn{4}{|l|}{ Control } \\
\hline ARPEGE & 5 & 4 & 0 \\
\hline CHRM & 9 & 2 & 1 \\
\hline CLM & 0 & 4 & 7 \\
\hline HadRM3P & 7 & 4 & 0 \\
\hline HIRHAM & 0 & 6 & 4 \\
\hline RegCM & 11 & 0 & 1 \\
\hline RACMO & 0 & 7 & 4 \\
\hline REMO & 0 & 5 & 7 \\
\hline PROMES & 0 & 0 & 12 \\
\hline $\mathrm{RCAO}$ & 4 & 4 & 0 \\
\hline \multicolumn{4}{|l|}{ A2 } \\
\hline \multicolumn{4}{|l|}{ Control } \\
\hline ARPEGE & 6 & 1 & 2 \\
\hline CHRM & 7 & 1 & 1 \\
\hline CLM & 0 & 11 & 0 \\
\hline HadRM3P & 10 & 0 & 0 \\
\hline HIRHAM & 0 & 5 & 7 \\
\hline RegCM & 11 & 1 & 0 \\
\hline RACMO & 0 & 7 & 5 \\
\hline REMO & 0 & 1 & 9 \\
\hline PROMES & 0 & 0 & 12 \\
\hline $\mathrm{RCAO}$ & 2 & 9 & 0 \\
\hline
\end{tabular}


Table A3. Number of sites out of the 6 under study where each member of the ensemble occupies a specific place in the ranking: analysis for winter wheat

\begin{tabular}{|c|c|c|c|}
\hline RCMs & Rank $<4$ & $4 \leq \operatorname{Rank} \leq 7$ & Rank $>7$ \\
\hline \multicolumn{4}{|l|}{ RAINFED } \\
\hline \multicolumn{4}{|l|}{ Control } \\
\hline ARPEGE & 5 & 0 & 0 \\
\hline CHRM & 1 & 0 & 4 \\
\hline CLM & 3 & 2 & 1 \\
\hline HadRM3P & 1 & 3 & 2 \\
\hline HIRHAM & 3 & 2 & 0 \\
\hline RegCM & 5 & 0 & 0 \\
\hline RACMO & 0 & 3 & 3 \\
\hline REMO & 0 & 5 & 1 \\
\hline PROMES & 0 & 0 & 6 \\
\hline RCAO & 0 & 3 & 1 \\
\hline \multicolumn{4}{|l|}{ A2 } \\
\hline \multicolumn{4}{|l|}{ Control } \\
\hline ARPEGE & 5 & 0 & 0 \\
\hline CHRM & 0 & 1 & 5 \\
\hline CLM & 4 & 2 & 0 \\
\hline HadRM3P & 1 & 0 & 4 \\
\hline HIRHAM & 3 & 2 & 0 \\
\hline RegCM & 5 & 0 & 1 \\
\hline RACMO & 0 & 1 & 3 \\
\hline REMO & 0 & 5 & 1 \\
\hline PROMES & 0 & 1 & 4 \\
\hline $\mathrm{RCAO}$ & 0 & 6 & 0 \\
\hline \multicolumn{4}{|l|}{ IRRIGAT. } \\
\hline \multicolumn{4}{|l|}{ Control } \\
\hline ARPEGE & 0 & 1 & 3 \\
\hline CHRM & 5 & 1 & 0 \\
\hline CLM & 0 & 0 & 6 \\
\hline HadRM3P & 3 & 2 & 0 \\
\hline HIRHAM & 0 & 5 & 0 \\
\hline RegCM & 5 & 0 & 0 \\
\hline RACMO & 1 & 3 & 2 \\
\hline REMO & 0 & 5 & 1 \\
\hline PROMES & 0 & 0 & 6 \\
\hline RCAO & 4 & 1 & 0 \\
\hline \multicolumn{4}{|l|}{ A2 } \\
\hline \multicolumn{4}{|l|}{ Control } \\
\hline ARPEGE & 0 & 1 & 3 \\
\hline CHRM & 4 & 0 & 2 \\
\hline CLM & 0 & 2 & 4 \\
\hline HadRM3P & 5 & 0 & 0 \\
\hline HIRHAM & 0 & 4 & 0 \\
\hline RegCM & 5 & 0 & 0 \\
\hline RACMO & 1 & 2 & 3 \\
\hline REMO & 0 & 5 & 1 \\
\hline PROMES & 0 & 1 & 5 \\
\hline RCAO & 3 & 3 & 0 \\
\hline
\end{tabular}

Editorial responsibility: Filippo Giorgi, Trieste, Italy
Submitted: October 12, 2010; Accepted: July 7, 2011 Proofs received from author(s): October 31, 2011 